\title{
Impact of Service Quality on Customer Satisfaction and Firm Performance in Nepalese Life Insurance Companies
}

\author{
Jitendra Prasad Upadhyay, Pitri Raj Adhikari
}

\begin{abstract}
This paper attempts to examine the impact of service quality on customer satisfaction and firm performance in Nepalese life insurance companies. Data are collected through structured and self-administered questionnaire from 350 respondents of 19 life insurance companies which are based on SERVQAL model. Descriptive and causal-comparative research design have used to achieve the objectives and descriptive statistics, correlation, as well as multiple regression models, have been used to analyze the data. It is observed that reliability, responsiveness, assurance, empathy, and tangibles have a positive and significant impact on customer satisfaction and firm performance. It is also found that responsiveness shows the highest positive correlation with customer satisfaction and performance in terms of ROA and assurance demonstrates the least positive correlation with customer satisfaction and ROA

Key Words: Customer satisfaction, Firm performance, Reliability, Responsiveness, Assurance, Empathy, Tangibles
\end{abstract}

\section{INTRODUCTION}

Customer satisfaction and firm performance are the researchable issues for practitioners and researchers for the last few decades. Prior research has linked customer satisfaction and firm performance with different predictors. Among them, service quality is one of the important predictors which is one of the most attractive areas for researchers over the last decade in the insurance sector. The increased emphasis on quality improvement has led firms to emphasize customer service. The premise of service quality is key for achieving competitive advantage and lead in a market-driven system has been well recognized by the financial institutions. Various research states that insurance companies must consider various antecedents of service quality i.e. reliability, responsiveness, assurance, empathy and tangibility to have delighted customers and to enhance their performance and profitability. The satisfaction level of customers depends on their perception of service quality and trust in the service provider. Kandampully (1998) stated customers are becoming increasingly critical of the quality of service they experience. Concept of service quality management is important to cope up with these fashionable competitive challenges one approach which has gained

Manuscript received on January 22, 2021.

Revised Manuscript received on February 15, 2021.

Manuscript published on February 28, 2021

* Correspondence Author

Jitendra Prasad Upadhyay*, Associate Professor, Commerce Campus, T. U, Nepal

Pitri Raj Adhikari, Lecturer, Shanker Dev Campus, T. U, Nepal

(C) The Authors. Published by Blue Eyes Intelligence Engineering and Sciences Publication (BEIESP). This is an open access article under the CC BY-NC-ND license (http://creativecommons.org/licenses/by-nc-nd/4.0/) momentum in the service industry is the concept of quality and quality management. According to Berry (1987) and Kim (2011), service quality has become a great differentiator and the most powerful competitive weapon with many leading service organizations possess. Customer satisfaction is positively affected by service quality factors (Lau et al., 2013; Maharjan, 2014; Khanal, 2015; Akhtar et al., 2016; Desai and Kahar, 2017; Shah, 2018; Shrestha, 2018, Myo et al., 2019; Ali et al., 2020). Similarly, Shah et al. (2018) observed that service attributes have a significant optimistic effect on customer satisfaction and Sari (2020) also revealed that the service quality variable has a significant effect on customer satisfaction. However, service assurance was found significantly negative predictor of customer satisfaction. Das and Jannat (2018) stated that among various dimensions of service quality, customers give more preference on reliability, assurance and tangibility. According to Stiakakis and Georgiadis (2009), reliability is a fundamental criterion of service quality and customers expect the services providers can perform the desired service dependably, accurately and consistently. Similarly, Ibáñez et al. (2006) examined a significant relationship between reliability of services and customers' satisfaction level. Likewise, Khan and Fasih (2014) found that reliability, tangibles, assurance have a positive and significant association with customer satisfaction that leads to better firms' performance. Responsiveness is the timely reaction towards the customers' need (Munusamy et al., 2010) and it is the only significant dimension of service quality which positively affects the satisfaction of customers (Demong et al., 2018; Ravichandran et al., 2010). Similarly, Khan (2010) stated that there is a positive relationship between responsiveness and customer satisfaction. Likewise, Greenberg (1990) revealed a positive and significant relationship of assurance, responsiveness, tangibility and empathy with customer satisfaction and firms' performance. Assurance is defined as employee's knowledge, courtesy and the ability of the firm's to inspire trust and confidence to the customers (Iwaarden et al., 2003) and it is positively related with customer satisfaction (Demong et al., 2018; Prakash and Sugumaran, 2014; Munusamy et al. 2010; Asubonteng et al., 1996). Empathy indicates the individualized attention that firms provide to their customers. Empathy can change the behaviour of customer ultimately and that had the highest influence on customer satisfaction (Lo et al., 2010). According to Iglesias and Guillen (2004),

Published By:

Blue Eyes Intelligence Engineering

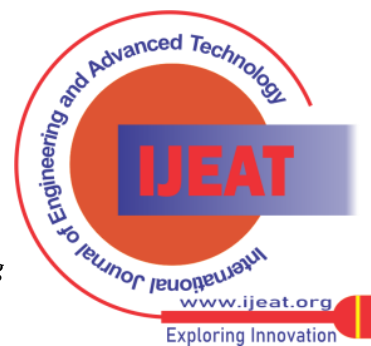




\section{Impact of Service Quality on Customer Satisfaction and Firm Performance in Nepalese Life Insurance Companies}

there is a positive and significant relationship of empathy with customer satisfaction. Similarly, tangibles such as customer impressions of tangible factors in terms of physical facilities, equipment and appearance of personnel had a positive influence on customer satisfaction

(Lau et al., 2013; Osman \& Sentosa, 2014). According to Irfan et al. (2014), service quality such as tangibility, empathy, assurance had positively influenced the profitability of an entity.

Service quality is one of the critical success factors that influence the service sectors, especially in insurance. An insurance company can differentiate itself from competitors by providing quality services at the promised time and there will be a positive impact on performance. Lohani and K. C. (2018) found the gap between expectation and perceptions of consumers in the Nepalese insurance sector. Moreover, research has been done regarding the issues in the western context, however, some research has been conducted in the context of Nepal. Hence, this paper attempts to examine the linkage of service quality with customer satisfaction and firm performance in Nepalese life insurance companies.

\section{RESEARCH HYPOTHESES}

This paper has set the following alternative hypotheses:

$\mathrm{H}_{1}$ : There is a positive relationship of reliability with customer satisfaction and firms' performance.

$\mathrm{H}_{2}$ : There is a positive relationship between responsiveness with customer satisfaction and firms' performance.

$\mathrm{H}_{3}$ : There is a positive relationship of assurance with customer satisfaction and firms' performance.

$\mathrm{H}_{4}$ : There is a positive relationship of empathy with customer satisfaction and firms' performance.

$\mathrm{H}_{5}$ : There is a positive relationship between tangibles with customer satisfaction and firms' performance.

\section{RESEARCH METHODS}

Descriptive research design, a process of accumulating facts and describes the phenomenon as it exists, has used for factfinding and identifies adequate information that affects service quality on customer satisfaction and firms' performance in Nepalese life insurance companies. It has also adopted the causal-comparative research design to identify the cause and effect relationship of service quality on customer satisfaction and firms' performance. Data are collected through a structured, self-administered questionnaire based on convenience sampling method of 350 respondents where the questionnaire was distributed to 570 respondents (response rate is 61.40 per cent) of 19 life insurance companies of Nepal and the questionnaire has divided into two sections where the first section is related with basic information of respondents and the next section is about Likert type questions regarding service quality variables that affect customer satisfaction and firms' performance which scale ranges from 1 (Strongly agree) to 5 (Strongly disagree). Customer satisfaction and firms' performances are dependent variables and reliability, responsiveness, assurance, empathy and tangibles are independent variables. Multiple regression models are used to analyze the interrelationship between service quality, customers' satisfaction and firms' performance. The paper has used the following multiple regression models:

Model 1:

$$
\begin{aligned}
C S=\alpha+\beta_{1} R E L & +\beta_{2} R E S+\beta_{3} A S S+\beta_{4} E M P+\beta_{5} T A N \\
& +\varepsilon \ldots \ldots \ldots \ldots \ldots(i)
\end{aligned}
$$

Model 2:

$$
\begin{aligned}
F P=\alpha+\beta_{1} R E L & +\beta_{2} R E S+\beta_{3} A S S+\beta_{4} E M P+\beta_{5} T A N \\
& +\varepsilon \ldots \ldots \ldots \ldots \ldots(i i)
\end{aligned}
$$

Where, $C S=$ Customer Satisfaction, $F P=$ Firm Performance, $R E L=$ Reliability, $R E S=$ Responsiveness, ASS $=$ Assurance,$E M P=$ Empathy, $T A N=$ Tangibles, $\varepsilon=$ error term, $\alpha=$ intercept of dependent variable, $\beta_{1}, \beta_{2}, \beta_{3}$ , $\beta_{4}$ and $\beta_{5}$ are the beta coefficient of explanatory variables to be estimated.

\section{Data Analysis}

\section{Descriptive statistics}

The mean value of the reliability in terms of customer satisfaction ranges from a minimum value of 1.69 to the maximum value of 1.98 and the weighted average is 1.78 that indicates Nepalese life insurance companies can satisfy the customers through reliability service. Similarly, the mean value of responsiveness ranges from the minimum value of 1.71 to the maximum value of 1.96 and the weighted average is 1.85 that means life insurance companies can satisfy the customers through responsiveness services. Likewise, the mean value of assurance ranges from the minimum value of 1.78 to the maximum value of 1.95 and the weighted average is 1.88 that states life insurance companies can satisfy the customers through assurance service. The mean value of the empathy ranges from the minimum value of 1.74 to a maximum value of 1.97 and the weighted average is 1.85 that states life insurance companies can satisfy the customers through empathy service. Additionally, the mean value of tangibles ranges from the minimum value of 1.76 to a maximum value of 1.91 and the weighted average is 1.86 which reveals life insurance companies can satisfy the customers through tangibles service. Furthermore, the mean value of customer satisfaction ranges from the minimum value of 1.74 to a maximum value of 2.02 and the weighted average is 1.91that indicates life insurance companies can satisfy the customers through service quality.

Correlation analysis

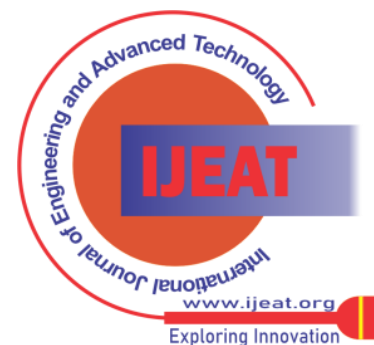


Correlation Matrix

Table 1

The table presents correlation coefficients based on 350 observations. The dependent variables are customer satisfaction and firm performance as indicated by return on assets. Reliability, responsiveness, assurance, empathy and tangibles are the independent variables.

\begin{tabular}{|c|c|c|c|c|c|c|c|c|c|}
\hline & Mean & S.D & REL & RES & ASS & EMP & TAN & CS & ROA \\
\hline REL & 1.78 & 0.568 & 1 & & & & & & \\
\hline RES & 1.85 & 0.603 & $0.689^{* *}$ & 1 & & & & & \\
\hline ASS & 1.88 & 0.588 & $0.712^{* *}$ & $0.703^{* *}$ & 1 & & & & \\
\hline EMP & 1.85 & 0.568 & $0.722^{* *}$ & $0.701^{* *}$ & $0.684^{* *}$ & 1 & & & \\
\hline TAN & 1.86 & 0.652 & $0.711^{* *}$ & $0.647^{* *}$ & $0.678^{* *}$ & $0.708^{* *}$ & 1 & & \\
\hline CS & 1.91 & 0.582 & $0.668^{* *}$ & $0.689^{* *}$ & $0.637^{* *}$ & $0.681^{* *}$ & $0.668^{* *}$ & 1 & \\
\hline RUA & 0.49 & 0.251 & $0.138^{*}$ & 0.182 & $0.091^{*}$ & $0.122^{*}$ & 0.094 & $0.129^{*}$ & 1 \\
\hline
\end{tabular}

Notes: The asterisk signs (**) indicates that the results are significant at the 1 per cent level.

Table 1 reveals that customer satisfaction is positively correlated with all independent variables that indicate higher the reliability, higher would be the customer satisfaction; increase in prompt response to the customer problem leads to increase in customer satisfaction; higher the assurance, higher would be the customer satisfaction; more the employees give personal or individual attention to the customer problem, higher would be the customer satisfaction; and better the tangibles, higher would be the customer satisfaction of Nepalese life insurance companies. Similarly, return on assets (firm performance) is positively correlated with all independent variables that show that higher the reliability, higher would be the firm performance; increase in prompt response to the customer problem, higher would be the firm performance; higher the assurance, higher would be the firm performance; more the employees give personal or individual attention to the customer problem, higher would be the firm performance; more the tangibility of services, higher would be the firm performance in the context of Nepalese life insurance companies.

\section{REGRESSION ANALYSIS}

Table 2

Regression Results of reliability, responsiveness, assurance, empathy and tangibles on customer satisfaction The table presents regression results based on the model: CS $=\alpha+\beta_{1}$ REL $+\beta_{2}$ RES $+\beta_{3}$ ASS $+\beta_{4}$ EMP $+\beta_{5}$ TAN $+\varepsilon$, where, $\mathrm{CS}=$ Customer Satisfaction, REL= Reliability, RES = Responsiveness, ASS= Assurance, EMP $=\mathrm{Empathy}$, TAN= Tangibles, $\varepsilon=$ error term, $\alpha=$ intercept of dependent variable, $\beta_{1}, \beta_{2}, \beta_{3}, \beta_{4}$ and $\beta_{5}$ are the beta coefficient of explanatory variables to be estimated.

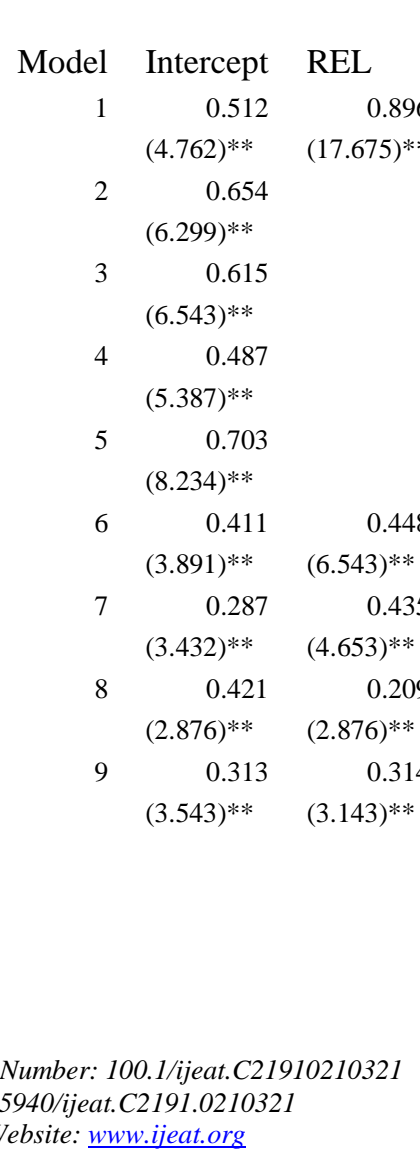

Regression coefficient of

RES ASS

RES

ASS

0.875

$(17.761)^{* *}$

0.981

$(17.824)^{* *}$

0.892

$(18.654)^{* *}$

0.315

$(16.287)^{* *}$

0.638

$(6.861)^{* *}$

0.243

$(4.456)^{* *}$

0.451

0.615

$(3.781)^{* *}$

$(3.961)^{* *}$

$(2.981)^{* *}$

0.271

$(4.141)^{* *}$

0.312

(3.613)**

$(3.002)^{* *}$
TAN

0.731

Adj.
$\mathrm{R}^{2}$

$\begin{array}{lll}0.871 & 0.423 \quad 316.891\end{array}$

$0.79 \quad 0.402 \quad 316.986$

$\begin{array}{lll}0.891 & 0.366 & 300.324\end{array}$

$0.871 \quad 0.445 \quad 335.98$

$\begin{array}{lll}0.751 & 0.432 & 259.879\end{array}$

$0.765 \quad 0.414 \quad 216.802$

$\begin{array}{lll}0.743 & 0.234 & 159.987\end{array}$

$0.981 \quad 0.421 \quad 129.751$

0.371

$(3.774)^{* *}$

0.723

$0.421 \quad 130.981$




Impact of Service Quality on Customer Satisfaction and Firm Performance in Nepalese Life Insurance Companies



Notes:
i. $\quad$ Figures in parenthesis are t-values
ii. $\quad *$ and ** represent the results are significant at 5 per cent and 1 per cent level respectively.
iii. Customer satisfaction is the dependent variable.

The table 2 states that positive and significant beta for reliability indicates customer satisfaction is positively affected by the reliability and this finding is similar to the findings of Stiakakis and Georgiadis (2009); Khan and Fasih (2014); and Iberahim et al. (2016). Similarly, the positive and significant beta for responsiveness with customer satisfaction reveals that responsiveness has a positive impact on customer satisfaction and this result is consistent to the findings of Khan (2010); Ravichandran et al.
(2010); Hussen (2015), and Fida et al., (2020). Likewise, the beta coefficients for the assurance with customer satisfaction are positive and significant that means it has a positive impact on customer satisfaction which is similar to the results of Munusamy et al. (2010). Additionally, the positive and significant beta for empathy with customer satisfaction indicates that empathy has a positive impact on customer satisfaction and these findings are consistent with the findings of Iglesias and Guillén (2004); and Fida et al. (2020). Moreover, the beta coefficient is positive and significant for tangibles with customer satisfaction that shows tangibles have a positive impact on customer satisfaction and it is similar to the results of Osman and Sentosa (2014).

\section{Table 3: Estimated regression results of reliability, responsiveness, assurance, empathy and tangibles on firm} performance (ROA)

The table presents regression results based on the model: $\mathrm{FP}=\alpha+\beta_{1} \mathrm{REL}+\beta_{2} \mathrm{RES}+\beta_{3} \mathrm{ASS}+\beta_{4} \mathrm{EMP}+\beta_{5} \mathrm{TAN}+\varepsilon$, where, FP $=$ Firm Performance, REL= Reliability, RES = Responsiveness, ASS $=$ Assurance, EMP $=$ Empathy, TAN= Tangibles, $\varepsilon=$ error term, $\alpha=$ intercept of dependent variable, $\beta_{1}, \beta_{2}, \beta_{3}, \beta_{4}$ and $\beta_{5}$ are the beta coefficient of explanatory variables to be estimated.

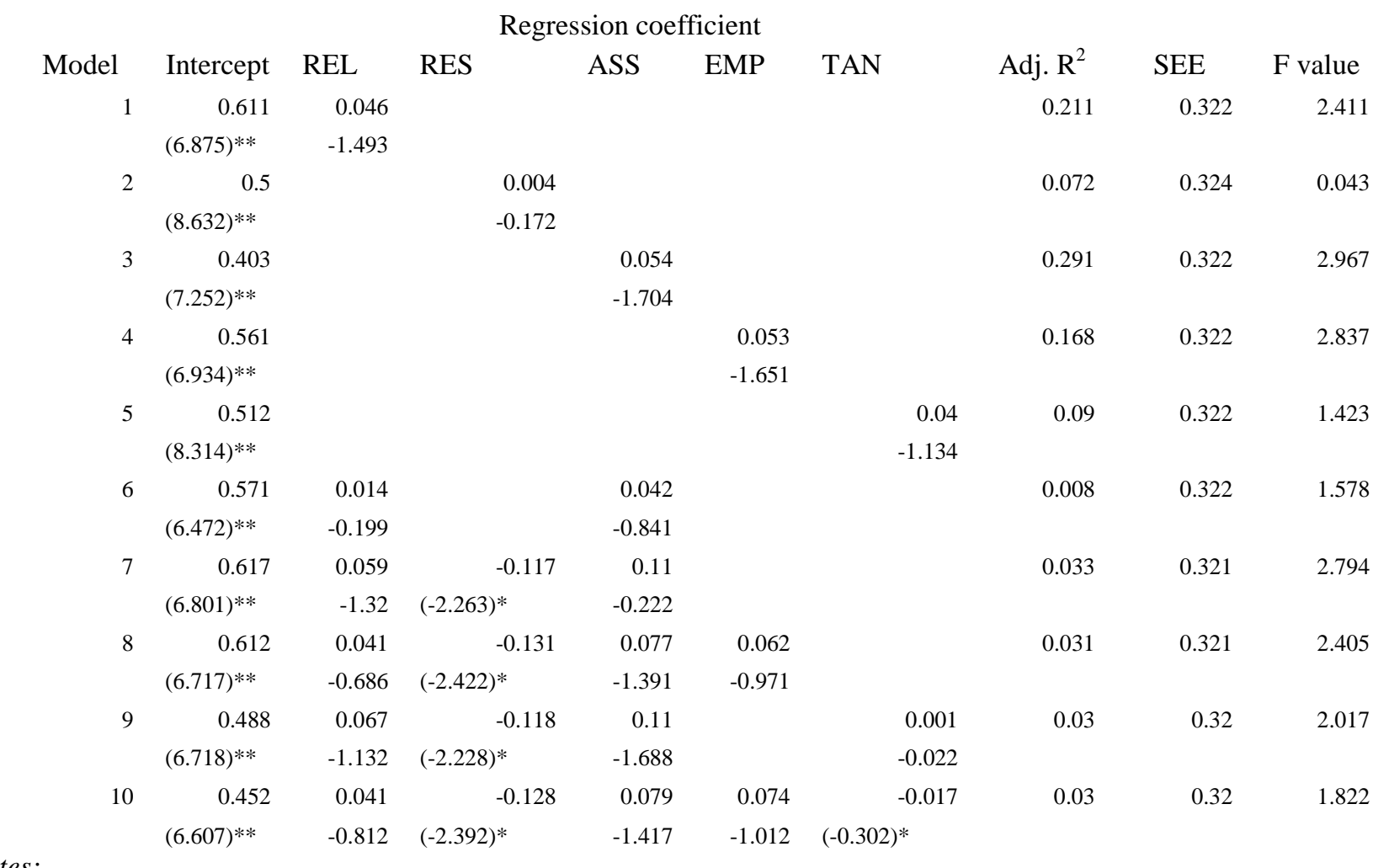

Notes:

i. $\quad$ Figures in parenthesis are t-values

ii. $\quad *$ and $* *$ represent the results are significant at 5 per cent and 1 per cent level respectively.

iii. $\quad$ Firm performance (ROA) is the dependent variable.

The table 3 shows that positive beta for reliability with ROA means reliability has a positive impact on firm performance and this result is similar to the findings of Khan and Fasih (2014). Similarly, the beta coefficients are positive for responsiveness with ROA that indicates responsiveness has a positive impact on firm performance and it is consistent with the result Greenberg (1990). Likewise, the result shows that positive beta coefficient for the assurance with ROA states assurance has a positive impact on firm performance and this finding is similar to the study of Maria and Katerina (2008). Additionally, beta coefficients for empathy are

positive with ROA that reveals empathy has a positive impact on firm performance and this finding is consistent with the findings of Al-Marri et al. (2007). Moreover, the result shows that positive beta for tangibles with ROA concludes that tangibles have a positive impact on firm performance and it is consistent with the results of Tax and Brown (1998).

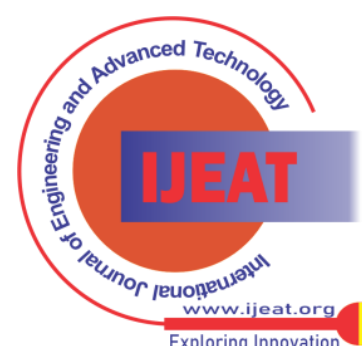




\section{CONCLUSION}

It is found that reliability, responsiveness, assurance, empathy, and tangibles are positively correlated with customer satisfaction and firm performance which reveals these variables have a positive and significant impact on customer satisfaction and firm performance. Further, it is observed that responsiveness shows the highest positive correlation with customer satisfaction and performance in terms of ROA and assurance demonstrates the least positive correlation with customer satisfaction and ROA. Further research can be conducted by using other variables such as creditability, customer orientation and competence which are related to service quality and customer satisfaction. In a future study, data can also be analyzed by using other techniques like structural equation modelling (SEM).

Last but not least, future research can also adopt customer continuance intention as a result of service quality. It is expected that the outcome of this paper will enable the life insurance companies of Nepal to design better strategies to satisfy the possible needs of customers to ensure that the number of policyholders will continue with the current policy they have purchased.

\section{REFERENCES}

1. Akhtar, N., Ahmad, A., Ahmad, H., Abbas, W., \& Abbas, T. N. (2016). Impact of service quality on customer satisfaction: A case of national bank of Pakistan. International Review of Management and Business Research, 5(2), 536-546.

2. Al-Marri, K., Ahmed, A. M. M. B., \& Zairi, M. (2007). Excellence in service: An empirical study of the UAE banking sector. International Journal of Quality and Reliability Management, 24(2), 164-176.

3. Ali, A., Abd. Majid, M. S., Azis, N., \& Hamid, A. (2020). Mediating the effects of customer satisfaction and bank reputation on the relationship between service quality and loyalty of Islamic banking customers. Malaysian Journal of Consumer and Family Economics, 25, 28-61.

4. Asubonteng, P., McCleary, K. J., \& Swan, J. E. (1996). SERVQUAL revisited: A critical review of service quality. Journal of Services Marketing, 10(6), 62-81.

5. Berry, L. (1987). Big ideas in services marketing. Journal of Services Marketing, 1(1), 5-9.

6. Das, S., \& Jannat, F. (2018). Impact of service quality on customers' satisfaction: An empirical study on state-owned commercial banks in Bangladesh. Dhaka University Journal of Management, 12(2), 31-48.

7. Demong, N. A. R., Othman, A. K., Yunus, N. H., \& Amran, N. A. W. (2018). Service quality factors and customer satisfaction on life insurance services. Journal of Islamic Management Studies, 2(1), 22 31.

8. Desai, M. P., \& Kahar, N. M. (2017). An evaluation of service quality City: A study based on SERVQUAL gap model. Journal of Commerce. Economics \& Computer Science (JCECS), 03(04), 121125.

9. Fida, B. A., Ahmed, U., Al-Balushi, Y., \& Singh, D. (2020). Impact of service quality on customer loyalty and customer satisfaction in Islamic banks in Sultanate of Oman. SAGE Open, April-June, 1-10.

10. Greenberg, J. (1990). Organizational justice: Yesterday, today and tomorrow. Journal of Management, 16(2), 399-432.

11. Hussen, S. (2015). Service quality, customers' satisfaction and loyalty: A study on insurance companies in Adama, Ethiopia. European Journal of Business and Management, 7(4), 269-276.

12. Ibáñez, V. A., Hartmann, P., \& Calvo, P. Z. (2006). Antecedents of customer loyalty in residential energy markets: Service quality, satisfaction, trust and switching costs. The Service Industries Journal, 26(6), 633-650.

13. Iberahim, H., Taufik, N. M., Adzmir, A. M., \& Saharuddin, H. (2016). Customer satisfaction on reliability and responsiveness of self-service technology for retail banking services. Procedia Economics and Finance, 37(1), 13-20.

14. Iglesias, M. P., \& Guillén, M. J. Y. (2004). Perceived quality and price: their impact on the satisfaction of restaurant customers. and customers' satisfaction of general insurance companies in Surat

International Journal of Contemporary Hospitality Management, 16(6), 373-379.

15. Irfan, R. S., Ghafoor, O., Akhtar, N., Hafeezz, I., \& Rehman, A. U. (2014). Factors affecting customer satisfaction in banking sector of Pakistan. International Review of Management and Business Research, 3(2), 1014-1025.

16. Kandampully, J. (1998). Service quality to service loyalty: A relationship which goes beyond customer services. Total quality management, 9(6), 431-443.

17. Khan, M. (2010). An empirical study of Automated Teller Machine service quality and customer satisfaction in Pakistani banks. Europeans Journal of Social Science, 13(3), 333-344.

18. Khan, M. M., \& Fasih, M. (2014). Impact of service quality and customer satisfaction and customer loyalty. International Journal of Scientific and Technology Research, 1(2), 106-110.

19. Khanal, B. (2015). Impact of service quality dimensions on customer satisfaction and customer loyalty in Nepalese commercial banks. Nepalese Journal of Business, 2(1), 41-52.

20. Kim, H. J. (2011). Service orientation, service quality, customer satisfaction, and customer loyalty: Testing a structural model. Journal of Hospitality Marketing \& Management, 20(6), 619-637.

21. Lau, M. M., Cheung, R., Lam, A. Y. C., \& Chu, Y. T. (2013). Measuring service quality in the banking industry: A Hong Kongbased study. Contemporary Management Research, 9(3), 263-282.

22. Lo, L. K., Osman, M., Ramayah, T., \& Rahim, M. (2010). The impact of $\quad$ service quality on customer loyalty: A study of banks in Penang, Malaysia. International Journal of Marketing Studies, 2(2), 57-66.

23. Lohani, S. P., \& K. C., F. B. (2018). Service quality in Nepalese insurance market. Nepalese Journal of Insurance and Social Security, 1(1). ISSN 2565-4942 eISSN 2738-9693.

24. Maharjan, M. (2014). Service quality, customer satisfaction and customer loyalty in commercial banks of Nepal. Nepalese Journal of Management, 1(1), 100-106.

25. Maria, N., \& Katerina, S. (2008). Standardization and quality in Greek banking services. Journal of Retailing, 89(6), 101-115.

26. Munusamy, J., Chelliah, S., \& Mun, H. W. (2010). Service quality delivery and its impact on customer satisfaction in the banking sector in Malaysia. International Journal of Innovation, Management and Technology, 1(4), 398-404.

27. Myo, Y. N., Khalifa, G. S. A., \& Aye, T. T. (2019). The impact of service quality on customer loyalty of Myanmar hospitality industry: The Mediating role of customer satisfaction. International Journal of Management and Human Science, 3(3), 1-11.

28. Osman, Z., \& Sentosa, I. (2014). Mediating effect of customer satisfaction on service quality and customer loyalty relationship in Malaysian rural tourism. International Journal of Economics Business and Management Studies, 2(1), 25-37.

29. Prakash, N., \& Sugumaran, G. (2014). An assessment of perceptions and expectations of customers in SERVQUAL parameters with reference to life insurance companies in Chennai, India. International Journal of Interdisciplinary and Multidisciplinary Studies (IJIMS), 1(6), 181-184.

30. Ravichandran, K., Prabakaran, S., \& Kumar, S. A. (2010) Application of servqual model on measuring service quality: A Bayesian approach. Enterprise Risk Management, 2(1), 16-25.

31. Sari, I. P. (2020). The effect of service quality, customer satisfaction and trust on customer loyalty in Pt Teleperformance Indonesia. HUMANIS (Humanities, Management, and Science Proceedings) 1(1), 278-283. Special issue: ICoMS2020. The $1^{\text {st }}$ International Conference on Management and Science.

32. Shah, P. K. (2018). Impact of service quality on customer satisfaction in Nepalese commercial banks. Nepalese Journal of Management, 5(1), 120-126.

33. Shah, S. N. U., Jan, S., \& Baloch, Q. B. (2018). Role of service quality and customer satisfaction in firm's performance: Evidence from Pakistan hotel industry. Pakistan Journal of Commerce and Social Sciences, 12(1), 167-182.

34. Shrestha, B. (2018). Impact of service quality on the customer satisfaction and customer loyalty in Nepalese telecommunication industry. 1-102.

35. Stiakakis, E., \& Georgiadis, C. K. (2009). E-service quality: Comparing the perceptions of providers and customers. Managing Service Quality: An International Journal, 19(4), 410-430.

Published By:

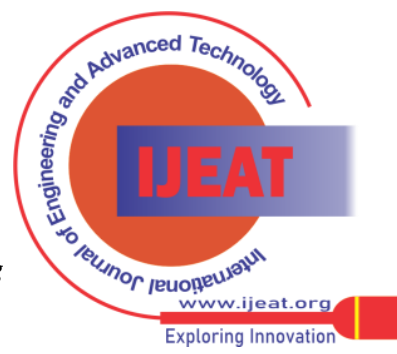


Impact of Service Quality on Customer Satisfaction and Firm Performance in Nepalese Life Insurance Companies

36. Tax, S. S., \& Brown, S. W. (1998). Recovering and learning from service failure. MIT Sloan Management Review, 40(1), 75-88.

\section{AUTHOR PROFILE}

Mr. Pitri Raj Adhikari is a Ph. D. scholar, and lecturer at Shanker Dev Campus, Tribhuvan University. He has written many research articles and textbooks in the management area. He has presented papers in national and international conferences and has participated in several workshops and seminars. He is a member of Finance Subject Committee at Shanker Dev Campus since 2008 AD.

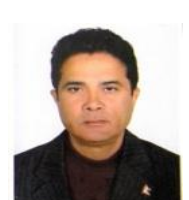

Jitendra Prasad Upadhyay (MBA, MPhil and Ph. D.), Associate Professor at Tribhuvan University, Nepal, coauthored books in Accounting and Management and published more than four dozens articles in Nepalese and International Journals. He has been participating different workshops and seminars in Nepal and India. He is a Standing Committee Member of Account Subject Committee at Tribhuvan University.

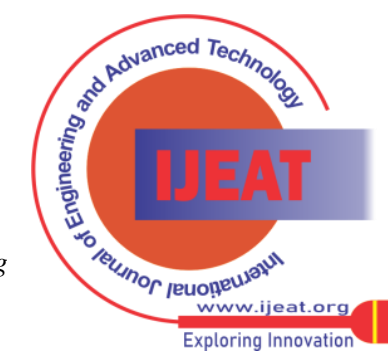

